\title{
A Short Review on Wrought Austenitic Stainless Steels at High Temperatures: Processing, Microstructure, Properties and Performance
}

\author{
Ronald Lesley Plaut ${ }^{\text {a }}$ Clara Herrera ${ }^{\text {b }}$ Doris Maribel Escriba ${ }^{\text {a* }}$, \\ Paulo Rangel Rios ${ }^{\mathrm{c}}$, Angelo Fernando Padilha ${ }^{\mathrm{a}}$ \\ aDepartamento de Engenharia Metalúrgica e de Materiais, Escola Politécnica, \\ Universidade de São Paulo - USP, Av. Prof. Mello Moraes, 2463, 05508-900 São Paulo - SP, Brazil \\ ${ }^{\mathrm{b}}$ Department for Microstructure Physics and Metal Forming, \\ Max-Planck-Institut für Eisenforschung, Düsseldorf, Germany \\ ${ }^{c}$ Escola de Engenharia Industrial Metalúrgica de Volta Redonda, \\ Universidade Federal Fluminense, Volta Redonda - RJ, Brazil
}

Received: June 1, 2007; Revised: October 16, 2007

\begin{abstract}
Wrought austenitic stainless steels are widely used in high temperature applications. This short review discusses initially the processing of this class of steels, with emphasis on solidification and hot working behavior. Following, a brief summary is made on the precipitation behavior and the numerous phases that may appear in their microstructures. Creep and oxidation resistance are, then, briefly discussed, and finalizing their performance is compared with other high temperature metallic materials.
\end{abstract}

Keywords: austenitic stainless steel, creep, oxidation, microstructural stability

\section{Introduction}

Stainless steels play an important role in the modern world, even if its tonnage represents only about $2 \%$ of the whole steel production. The 2005 total steel production surpassed $10^{9}$ tons. Austenitic stainless steels (ASSs) were invented in Essen, Germany, in the beginning of the $20^{\text {th }}$ century and represent today more than $2 / 3$ of the total stainless steel world production ${ }^{1,2}$. Their continuing development has resulted in complex steel compositions with substantial amounts of alloying elements. These alloying elements are of course introduced in the steel for one or more reasons but the final aim is mainly to obtain better mechanical properties (especially high creep strength and high creep-rupture ductility) and/or higher corrosion resistance (especially oxidation resistance in the case of high temperature application). As usual, the benefits of such additions invariably come attached to unavoidable disadvantages of which the most important are the potential microstructural instability and difficult processing of the material. A concise overview is given on the processing, microstructure, properties and performance of wrought ASSs at high temperatures.

\section{Chemical Compositions}

Austenitic stainless steels constitute a very large steel class in terms of alloys and usage. Table 1 presents the main alloying elements and their corresponding composition range. In addition to iron, the main components are $\mathrm{Cr}$ to improve corrosion resistance and $\mathrm{Ni}$ to stabilize austenite. Chromium contents range from 15 to $26 \mathrm{wt}$. (\%) and nickel contents from 5 to $37 \mathrm{wt}$. (\%). The 200 series has a lower $\mathrm{Ni}$ content than the 300 series. These steels have a high Mn content up to 15.5 wt. (\%) and also a high $\mathrm{N}$ content that partly replaces $\mathrm{Ni}$ as austenite stabilizer. In some steels one can find 2 to 4 wt. (\%) of molybdenum. Mo is primarily introduced to improve the resistance against pitting corrosion but it is also efficient in promoting solid solution hardening. More recently developed steels, known as superaustenitic stainless steels, can contain up to 6 wt. (\%) Mo. The term superaustenitic relates to austenitic stainless steels containing high amounts of chromium, nickel, molybdenum and nitrogen, resulting in an iron content close to or less than $50 \mathrm{wt}$. (\%). One of the most well known superaustenitic stainless steels is the UNS S32654 (also known as $654 \mathrm{SMO}^{\circledR}$ ): Fe-0.02C-3Mn-24Cr-7.3Mo-22Ni-0.5Cu-0.5N (wt. (\%)). In most of the steels shown in Table 1 the maximum silicon content is 1 wt. (\%). However, higher $\mathrm{Si}$ contents between 1 and 3 wt. (\%) can improve oxidation or scaling resistance. Even higher Si contents up to $5 \mathrm{wt}$. (\%) are used in certain cases to improve the corrosion resistance in nitric acid. Other alloying elements such as copper, boron or sulfur are sometimes added to the austenitic stainless steels and will be mentioned during the course of this review. Using lowcarbon-content (such as AISI 304L, 316L and 317L) or/and titanium or niobium stabilized alloys (such as AISI 321 and 347) it is possible to minimize intergranular attack in austenitic stainless steels.

\section{Processing}

Stainless steels can solidify (Figure 1) by several mechanisms or modes: ferritic or mode $\mathrm{A}(\mathrm{L} \rightarrow \mathrm{L}+\delta \rightarrow \delta$ ); ferritic-austenitic or mode $\mathrm{B}(\mathrm{L} \rightarrow \mathrm{L}+\delta \rightarrow \mathrm{L}+\delta+\gamma \rightarrow \gamma+\delta)$; austenitic-ferritic or mode $\mathrm{C}(\mathrm{L} \rightarrow \mathrm{L}+\gamma \rightarrow \mathrm{L}+\gamma+\delta \rightarrow \gamma+\delta)$ and austenitic or mode $\mathrm{D}$ $(\mathrm{L} \rightarrow \mathrm{L}+\gamma \rightarrow \gamma)$. Their solidification mode and sequence may also be successfully predicted using chromium and nickel equivalent ratios ${ }^{3}$.

The vast majority of austenitic stainless steels present delta ferrite in their microstructure just following its solidification. Apart from $\mathrm{Fe}$, $\mathrm{Cr}$ and $\mathrm{Ni}$ they contain other chemical elements that are classified as ferrite formers $(\mathrm{Cr}, \mathrm{Mo}, \mathrm{Si}$ ) or austenite formers $(\mathrm{Ni}, \mathrm{N}, \mathrm{C}, \mathrm{Mn}, \mathrm{Cu})$. The efficiency of these elements as ferrite and austenite stabilizers can be compared to the ones of $\mathrm{Cr}$ and $\mathrm{Ni}$ (equivalency). Among several equations for chromium equivalent, $\mathrm{Cr}_{\mathrm{eq}}$ and nickel equivalent, $\mathrm{Ni}_{\mathrm{eq}}$ one can quote the following ${ }^{4}$ :

$$
\mathrm{Cr}_{\mathrm{eq}}=\mathrm{Cr}+1.37 \mathrm{Mo}+1.5 \mathrm{Si}+2 \mathrm{Nb}+3 \mathrm{Ti}
$$


Table 1. Chemical compositions (in weight \%) of some typical ASSs ${ }^{1}$.

\begin{tabular}{|c|c|c|c|c|c|c|c|c|c|}
\hline Type & $\begin{array}{c}\text { UNS } \\
\text { designation }\end{array}$ & $\mathrm{C}$ & $\mathrm{Mn}$ & $\mathrm{Si}$ & $\mathrm{Cr}$ & $\mathrm{Ni}$ & Mo & $\mathrm{N}$ & Others \\
\hline AISI 201 & S20100 & $\leq 0.15$ & $5.50-7.50$ & $\leq 1.00$ & $16.00-18.00$ & $3.50-5.50$ & - & 0.25 & - \\
\hline AISI 202 & S20200 & $\leq 0.15$ & $7.50-10.0$ & $\leq 1.00$ & $17.00-19.00$ & $4.0-6.0$ & - & 0.25 & - \\
\hline AISI 205 & S20500 & $0.12-0.25$ & $14.0-15.5$ & $\leq 1.00$ & $16.50-18.00$ & $1.0-1.75$ & - & $0.32-0.40$ & - \\
\hline AISI 301 & S30100 & $\leq 0.15$ & $\leq 2.00$ & $\leq 1.00$ & $16.00-18.00$ & $6.0-8.0$ & - & - & - \\
\hline AISI 302 & S30200 & $\leq 0.15$ & $\leq 2.00$ & $\leq 1.00$ & $17.00-19.00$ & $8.0-10.0$ & - & - & - \\
\hline AISI 303 & S30300 & $\leq 0.15$ & $\leq 2.00$ & $\leq 1.00$ & $17.00-19.00$ & $8.0-10.0$ & 0.6 & - & - \\
\hline AISI 304 & S30400 & $\leq 0.08$ & $\leq 2.00$ & $\leq 1.00$ & $18.00-20.00$ & $8.0-10.5$ & - & - & - \\
\hline AISI $304 \mathrm{H}$ & S30409 & $0.04-0.10$ & $\leq 2.00$ & $\leq 1.00$ & $18.00-20.00$ & $8.0-10.5$ & - & - & - \\
\hline AISI 304L & S30403 & $\leq 0.03$ & $\leq 2.00$ & $\leq 1.00$ & $18.00-20.00$ & $8.0-12.0$ & - & - & - \\
\hline AISI 304N & S30400 & $\leq 0.08$ & $\leq 2.00$ & $\leq 1.00$ & $18.00-20.00$ & $8.0-10.5$ & - & $0.10-0.16$ & - \\
\hline AISI 304LN & S30451 & $\leq 0.03$ & $\leq 2.00$ & $\leq 1.00$ & $18.00-20.00$ & $8.0-12.0$ & - & $0.10-0.16$ & - \\
\hline AISI 308 & S30800 & $\leq 0.08$ & $\leq 2.00$ & $\leq 1.00$ & $19.00-21.00$ & $10.0-12.0$ & - & - & - \\
\hline AISI 309 & S30900 & $\leq 0.20$ & $\leq 2.00$ & $\leq 1.00$ & $22.00-24.00$ & $12.0-15.0$ & - & - & - \\
\hline AISI 310 & S31000 & $\leq 0.25$ & $\leq 2.00$ & $\leq 1.00$ & $24.00-26.00$ & $19.0-22.0$ & - & - & - \\
\hline AISI 316 & S31600 & $\leq 0.08$ & $\leq 2.00$ & $\leq 1.00$ & $16.00-18.00$ & $10.0-14.0$ & $2.0-3.0$ & - & - \\
\hline AISI $316 \mathrm{H}$ & S31609 & $\leq 0.08$ & $\leq 2.00$ & $\leq 1.00$ & $16.00-18.00$ & $10.0-14.0$ & $2.0-3.0$ & - & - \\
\hline AISI 316L & S31603 & $\leq 0.03$ & $\leq 2.00$ & $\leq 1.00$ & $16.00-18.00$ & $10.0-14.0$ & $2.0-3.0$ & - & - \\
\hline AISI 316LN & S31653 & $\leq 0.03$ & $\leq 2.00$ & $\leq 1.00$ & $16.00-18.00$ & $10.0-14.0$ & $2.0-3.0$ & $0.10-0.16$ & - \\
\hline AISI 316N & S31651 & $\leq 0.08$ & $\leq 2.00$ & $\leq 1.00$ & $16.00-18.00$ & $10.0-14.0$ & $2.0-3.0$ & $0.10-0.16$ & - \\
\hline AISI 317 & S31700 & $\leq 0.08$ & $\leq 2.00$ & $\leq 1.00$ & $18.00-20.00$ & $11.0-15.0$ & $3.0-4.0$ & - & - \\
\hline AISI 317L & S31703 & $\leq 0.03$ & $\leq 2.00$ & $\leq 1.00$ & $18.00-20.00$ & $11.0-15.0$ & $3.0-4.0$ & - & - \\
\hline AISI 321 & S32100 & $\leq 0.08$ & $\leq 2.00$ & $\leq 1.00$ & $17.00-19.00$ & $9.0-12.0$ & - & - & $\mathrm{Ti} \geq 5 \times \% \mathrm{C}$ \\
\hline AISI $321 \mathrm{H}$ & S32109 & $0.04-0.10$ & $\leq 2.00$ & $\leq 1.00$ & $17.00-19.00$ & $9.0-12.0$ & - & - & $\mathrm{Ti} \geq 5 \times \% \mathrm{C}$ \\
\hline AISI 347 & S34700 & $\leq 0.08$ & $\leq 2.00$ & $\leq 1.00$ & $17.00-19.00$ & $9.0-13.0$ & - & - & $\mathrm{Nb} \geq 10 \times \% \mathrm{C}$ \\
\hline AISI $347 \mathrm{H}$ & S34709 & $0.04-0.10$ & $\leq 2.00$ & $\leq 1.00$ & $17.00-19.00$ & $9.0-13.0$ & - & - & $1.0 \geq \mathrm{Nb} \geq 10 \times \% \mathrm{C}$ \\
\hline $654 \mathrm{SMO}^{\circledast}$ & S32654 & $\leq 0.02$ & $2.00-4.00$ & $\leq 0.50$ & $24.0-25.0$ & $21.0-23.0$ & $7.0-8.0$ & $0.45-0.55$ & $\mathrm{Cu}=0.30-0.60$ \\
\hline
\end{tabular}

$($ AISI $=$ american iron and steel institute; UNS = unified numbering system).

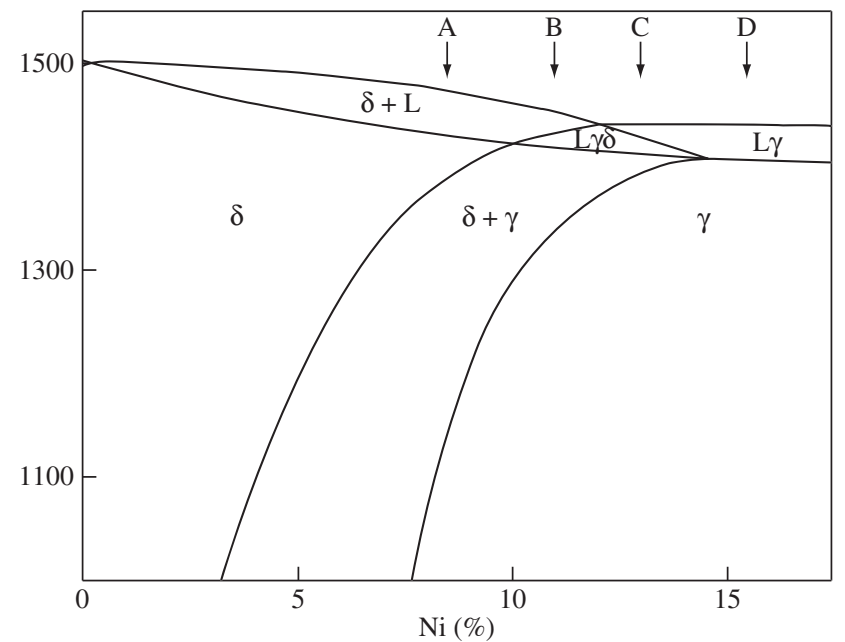

Figure 1. Temperature $\left({ }^{\circ} \mathrm{C}\right)$ vs. nickel content (in wt. (\%)). Section through Fe$\mathrm{Ni}-\mathrm{Cr}$ phase diagram at $19 \mathrm{wt}$. (\%) $\mathrm{Cr}$ showing four solidification modes ${ }^{3}$.

$$
\mathrm{Ni}_{\mathrm{eq}}=\mathrm{Ni}+0.3 \mathrm{Mn}+22 \mathrm{C}+14.2 \mathrm{~N}+\mathrm{Cu}
$$

where all the elements are introduced into the formula in wt. (\%).

Ferrite has a negative influence on hot ductility ${ }^{5-9}$ because ferrite and austenite present different softening mechanisms at high defor- mation temperatures; while ferrite recovers austenite recrystallizes leading to interface fracture. In the majority of the cases delta ferrite may be eliminated by long period homogenizing heat treatments ${ }^{10}$ in the 1050 to $1250{ }^{\circ} \mathrm{C}$ temperature range. However, due to economical reasons this is not performed in the steel mills, at least in a complete manner.

After solidification, via conventional or continuous casting, wrought austenitic stainless steels are, in general, hot worked. Several factors influence hot ductility of the ASSs: temperature, strain, strain rate, chemical composition, grain size and orientation, non-metallic inclusions and prior mechanical or thermal heat treatments ${ }^{5,11}$. The analysis of the effects of the alloying elements on the hot ductility of the ASSs presents increased difficulties due to the fact that practically all alloying elements and impurities influence the amount of delta ferrite that is formed. Figure 2 shows ${ }^{11}$ the hot ductility variations, evaluated by hot tensile testing at a constant strain rate of $6 \mathrm{~s}^{-1}$, for several additions to the base-composition of the AISI 304L steel. The curves present similar shapes and can be divided into three stages. In the 900 to $1000{ }^{\circ} \mathrm{C}$ temperature range, ductility is low, but significantly increases in the 1100 to $1200{ }^{\circ} \mathrm{C}$ range due to dynamic recrystallization. Ductility loss verified for temperatures over $1250-1350{ }^{\circ} \mathrm{C}$ is related to the lack of grain boundary cohesion and eventually with the occurrence of some liquation. It may be observed that while small $\mathrm{Ti}$ additions enhance hot ductility of the $304 \mathrm{~L}$ steel, all other additions ( $\mathrm{N}, \mathrm{Cr}, \mathrm{Ni}, \mathrm{Mo}, \mathrm{S}, \mathrm{C}$ and $\mathrm{Mn}+\mathrm{Si}$ ) have a negative effect. 
In the case of the AISI 316 steel, minor B additions (40-90 ppm), improve hot ductility ${ }^{11}$.

Finally it should be mentioned that cold working introduces into the microstructure of the majority of the ASSs a significant amount of strain induced martensite ${ }^{12-17}$. These martensites may revert back into austenite during subsequent annealing, even for temperatures that are lower than the temperature for static recrystallization ${ }^{12-14}$. The ASSs are generally supplied in the solution annealed condition, performed in the temperature range of 1000 to $1120^{\circ} \mathrm{C}^{1}$. In the case of the stabilized steels, which are more prone to secondary recrystallization or abnormal grain growth ${ }^{18,19}$, as compared to the nonstabilized steels, the solution annealing temperature range should be at a lower level ${ }^{1}$. As previously mentioned, the most common steels such as AISI 304L, 316L, 321 and 347 are supplied in the solution annealed condition. Nevertheless, they invariably contain some residual delta ferrite in their microstructure.

\section{Microstructure}

The matrix microstructure of the austenitic steels is a solid solution, with a very low stacking fault energy and a high work hardening capability ${ }^{20-23}$. Table 2 presents information on the main intermetallic phases, carbides, nitrides, borides and sulfides that may occur in stainless steels ${ }^{1,2}$. A very large number of phases can be present in the microstructure of ASSs, mainly carbides and intermetallic phases ${ }^{1,2,24-35}$. Carbides that are more frequent are the $\mathrm{M}_{23} \mathrm{C}_{6}$ and MC type, the latter ones are present in the stabilized steels. The intermetallic phases that are more common in these steels are the sigma $(\sigma)$, Laves and chi $(\chi)$ phases. Figure 3 gives an overall view in a schematic TTT diagram of the different heat treatments and transformations that can occur in the ASSs.

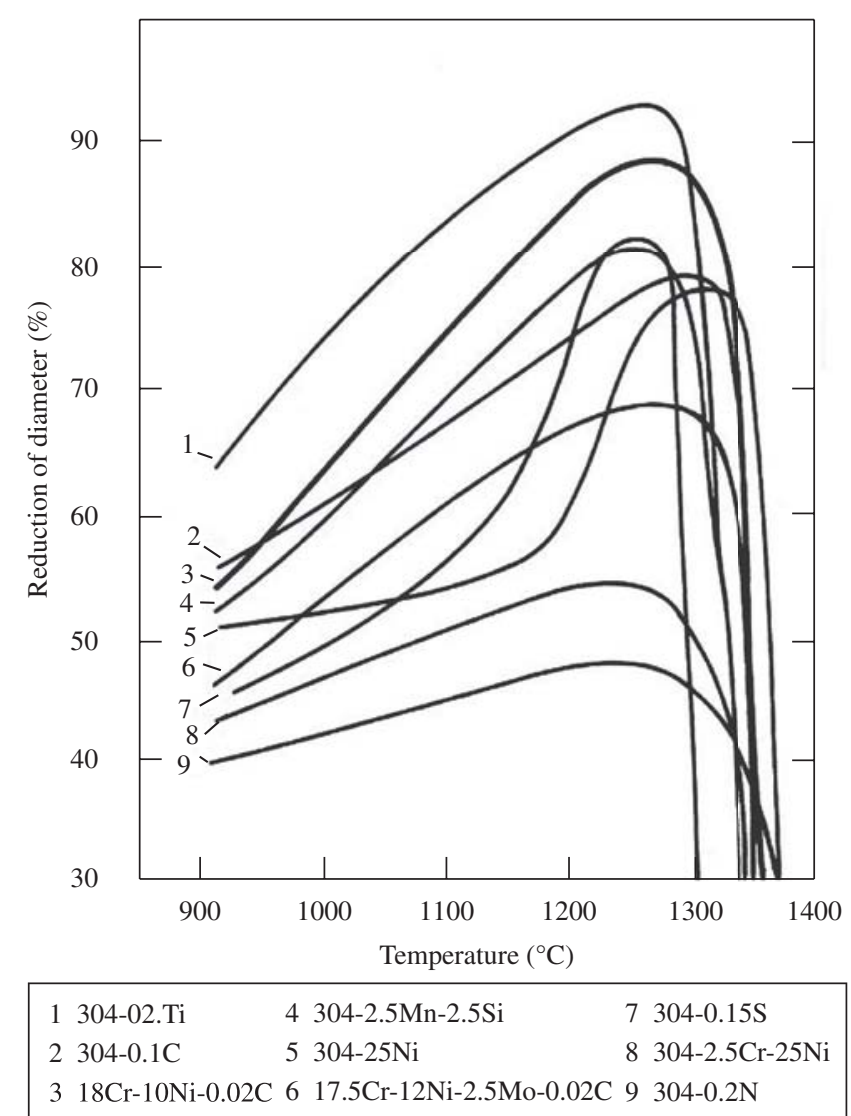

Figure 2. Effect of alloying elements on hot ductility of the AISI 304L (A1loy 3 ) austenitic stainless steels ${ }^{11}$. All the compositions are in wt. (\%).

\section{Properties}

The two main requirements that materials aimed at high temperature applications should comply with are oxidation and creep resistance.

Equipment or components exposed to high temperatures are susceptible to several external attacks such as oxidation, carburization, sulfidation, nitridation, halogen gas corrosion, ash or salt deposit corrosion, molten salt corrosion and molten metal corrosion. Oxidation is the most important high-temperature corrosion reaction $^{36,37}$. Figure 4 shows the temperature range for which different ferrous materials present a satisfactory oxidation resist-

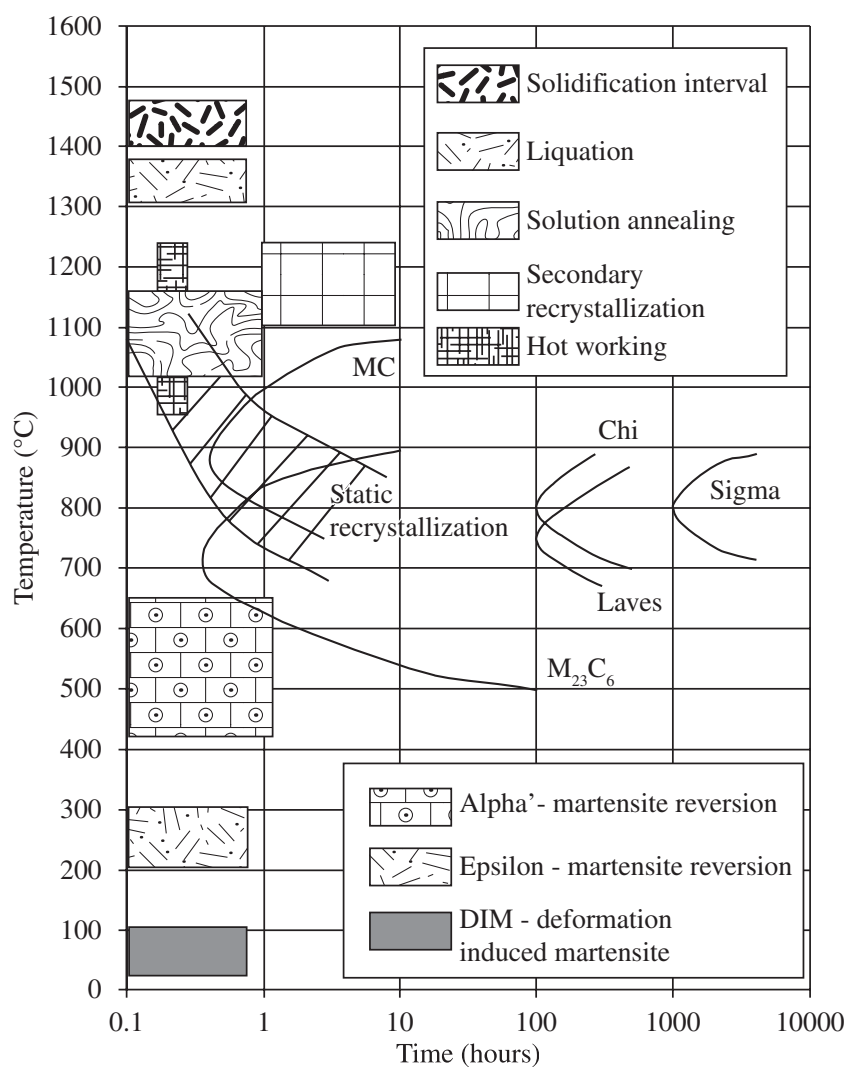

Figure 3. Main transformations that occur in austenitic stainless steels between room temperature and the liquid state ${ }^{13}$.

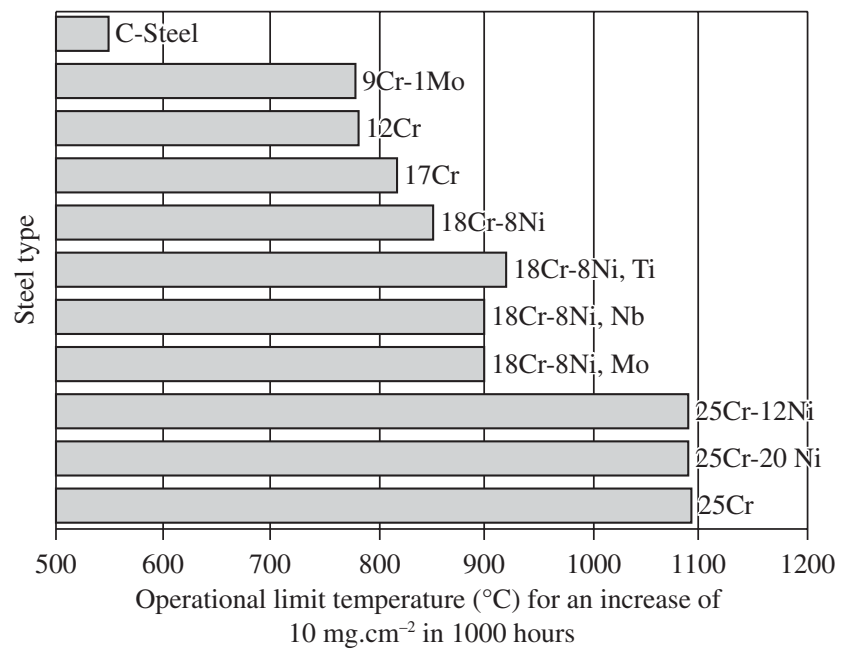

Figure 4. Influence of the chemical composition, especially the $\mathrm{Cr}$ content, on the oxidation resistance of steels ${ }^{37}$. All compositions are in wt. (\%). 
Table 2. Crystal structures and compositions of phases that may occur in stainless steels ${ }^{1,2}$.

\begin{tabular}{|c|c|c|c|c|c|}
\hline Phase & Unit cell & Atoms per cell & Space group & Lattice parameters $(\mathrm{nm})$ & Composition \\
\hline \multicolumn{6}{|c|}{ Intermetallic phases } \\
\hline $\operatorname{Sigma}(\sigma)$ & bct & 30 & $\mathrm{P}_{2} / \mathrm{mnm}$ & $\begin{array}{l}\mathrm{a}=0.87-0.92 \\
\mathrm{c}=0.4554-0.48\end{array}$ & $(\mathrm{Fe}, \mathrm{Ni})_{x}(\mathrm{Cr}, \mathrm{Mo})_{y}$ \\
\hline Chi $(\chi)$ & bcc & 58 & $\mathrm{I} 43 \mathrm{~m}$ & $\mathrm{a}=0.881-0.895$ & $\begin{array}{l}\mathrm{Fe}_{36} \mathrm{Cr}_{12} \mathrm{Mo}_{10} \\
(\mathrm{Fe}, \mathrm{Ni})_{36} \mathrm{Cr}_{18} \mathrm{Mo}_{4}\end{array}$ \\
\hline Laves $(\eta)$ & hex. & 12 & $\mathrm{P}_{3} / \mathrm{mmc}$ & $\begin{array}{l}a=0.473-0.483 \\
c=0.772-0.786\end{array}$ & $\mathrm{Fe}_{2} \mathrm{Mo} ; \mathrm{Fe}_{2} \mathrm{Nb} ; \mathrm{Fe}_{2} \mathrm{Ta} ; \mathrm{Fe}_{2} \mathrm{Ti} ; \mathrm{Fe}_{2} \mathrm{~W}$ \\
\hline G & fcc & 116 & $\mathrm{Fd} 3 \mathrm{~m}$ & $\mathrm{a}=1.115-1.120$ & $\mathrm{Ni}_{16} \mathrm{Nb}_{6} \mathrm{Si}_{7} ; \mathrm{Ni}_{16} \mathrm{Ti}_{6} \mathrm{Si}_{7} ;(\mathrm{Ni}, \mathrm{Fe}, \mathrm{Cr})_{16}(\mathrm{Nb}, \mathrm{Ti})_{6} \mathrm{Si}_{7}$ \\
\hline $\mathrm{R}$ & hex. & $53(159)$ & R3 & $\begin{array}{l}\mathrm{a}=1.090 \\
\mathrm{c}=1.934\end{array}$ & $\begin{array}{l}\mathrm{Fe}_{22} \mathrm{Mo}_{18} \mathrm{Cr}_{13} \\
(\mathrm{Fe}, \mathrm{Ni})_{10} \mathrm{Cr}_{5} \mathrm{Mo}_{3} \mathrm{Si}_{2}\end{array}$ \\
\hline $\mathrm{Mu}(\mu)$ & rhombohedral & 13 & $\mathrm{R} 3 \mathrm{~m}$ & $\begin{array}{l}\mathrm{a}=0.4762 \\
\mathrm{c}=2.5015\end{array}$ & $\begin{array}{l}(\mathrm{Fe}, \mathrm{Co})_{7}(\mathrm{Mo}, \mathrm{W})_{6} \\
(\mathrm{Cr}, \mathrm{Fe})_{7}(\mathrm{Mo})_{2}(\mathrm{Cr}, \mathrm{Fe}, \mathrm{Mo})_{4}\end{array}$ \\
\hline$\gamma^{\prime}$ & fcc & 4 & Pm3m & $\mathrm{a}=0.3565-0.3601$ & $(\mathrm{Ni}, \mathrm{Co}, \mathrm{Fe}, \mathrm{Cr})_{3}(\mathrm{Al}, \mathrm{Ti})$ \\
\hline$\gamma "$ & bct & 8 & $\begin{array}{l}\mathrm{P} 4_{2} / \mathrm{mnm} \\
\mathrm{I} 4 / \mathrm{mmm}\end{array}$ & $\begin{array}{l}a=0.3624 \\
c=0.7406\end{array}$ & $\mathrm{Ni}_{3} \mathrm{Nb}$ \\
\hline$\eta$ & hex. & 8 & $\mathrm{P}_{3} / \mathrm{mmc}$ & $\begin{array}{l}\mathrm{a}=0.5109 \\
\mathrm{c}=0.8299\end{array}$ & $\mathrm{Ni}_{3} \mathrm{Ti}$ \\
\hline$\delta$ & orthorombic & 8 & Pmmn & $\begin{array}{l}a=0.5116 \\
b=0.4259 \\
c=0.4565\end{array}$ & $\mathrm{Ni}_{3} \mathrm{Nb}$ \\
\hline$\beta$ & ord bcc & 2 & Pm3m & $\mathrm{a}=0.2865-0.2887$ & $\mathrm{NiAl}$ \\
\hline \multicolumn{6}{|c|}{ Carbides } \\
\hline $\mathrm{M}_{23} \mathrm{C}_{6}$ & fcc & 116 & Fm3m & $\mathrm{a}=1.057-1.068$ & $\begin{array}{l}(\mathrm{Cr}, \mathrm{Fe}, \mathrm{Mo})_{23} \mathrm{C}_{6} \\
\left(\mathrm{Cr}_{16} \mathrm{Fe}_{5} \mathrm{Mo}_{2}\right) \mathrm{C}_{6}\end{array}$ \\
\hline $\mathrm{MC}$ & ord fcc & 8 & Fm3m & $a=0.4131-0.4698$ & $(\mathrm{Ti}, \mathrm{Nb}, \mathrm{V}) \mathrm{C}$ \\
\hline $\mathrm{M}_{6} \mathrm{C}$ & $\mathrm{fcc}$ & 112 & $\mathrm{Fd} 3 \mathrm{~m}$ & $\mathrm{a}=1.085-1.128$ & $(\mathrm{Fe}, \mathrm{Mo}, \mathrm{Nb}, \mathrm{Cr}, \mathrm{Si})_{6} \mathrm{C}$ \\
\hline $\mathrm{M}_{7} \mathrm{C}_{3}$ & pseudo hex. & 40 & Pnma & $\begin{array}{l}\mathrm{a}=1.398 \\
\mathrm{c}=0.4523\end{array}$ & $(\mathrm{Cr}, \mathrm{Fe})_{7} \mathrm{C}_{3}$ \\
\hline \multicolumn{6}{|c|}{ Nitrides } \\
\hline MN & ord fcc & 8 & Fm3m & $\mathrm{a}=0.4097-0.4577$ & $\begin{array}{l}\mathrm{ZrN} ; \mathrm{TiN} \\
\mathrm{NbN} ; \mathrm{VN}\end{array}$ \\
\hline $\mathrm{M}_{2} \mathrm{~N}$ & hexagonal & 9 & P31m & $\begin{array}{l}\mathrm{a}=0.478-0.480 \\
\mathrm{c}=0.444-0.447\end{array}$ & $(\mathrm{Cr}, \mathrm{Fe})_{2} \mathrm{~N}$ \\
\hline Z-phase & tetragonal & 6 & $\mathrm{P} 4 / \mathrm{nmm}$ & $\begin{array}{l}\mathrm{a}=0.3037 \\
\mathrm{c}=0.7391\end{array}$ & $\mathrm{CrNNb}$ \\
\hline \multicolumn{6}{|c|}{ Borides } \\
\hline $\mathrm{M}_{2} \mathrm{~B}$ & orthorhombic & 48 & Fddd & $\begin{array}{l}a=1.4585 \\
b=0.7331 \\
c=0.4223\end{array}$ & $\mathrm{Cr}_{1.04} \mathrm{Fe}_{0.96} \mathrm{~B}$ \\
\hline $\mathrm{M}_{3} \mathrm{~B}_{2}$ & tetragonal & 10 & $\mathrm{P} 4 / \mathrm{mbm}$ & $\begin{array}{l}a=0.5807 \\
c=0.3142\end{array}$ & $\mathrm{FeMo}_{2} \mathrm{~B}_{2}$ \\
\hline \multicolumn{6}{|c|}{ Sulfides } \\
\hline $\mathrm{M}_{4} \mathrm{C}_{2} \mathrm{~S}_{2}$ & hexagonal & 8 & $\mathrm{P}_{3} / \mathrm{mmc}$ & $\begin{array}{l}\mathrm{a}=0.320-3.39 \\
\mathrm{c}=1.118-1.210\end{array}$ & $\begin{array}{l}\mathrm{Ti}_{4} \mathrm{C}_{2} \mathrm{~S}_{2} \\
\mathrm{Zr}_{4} \mathrm{C}_{2} \mathrm{~S}_{2}\end{array}$ \\
\hline
\end{tabular}

ance. As expected, the maximum temperature raises with the steel chromium content. The basic mechanism involves the formation of a $\mathrm{Cr}_{2} \mathrm{O}_{3}$ and/or a $\mathrm{FeCr}_{2} \mathrm{O}_{4}$ spinel protective film ${ }^{36-39}$. Addition of rare-earth elements to alloys produces a substantial increase in their resistance to high-temperature oxidation ${ }^{40,41}$. Recently, a group of $\mathrm{Al}_{2} \mathrm{O}_{3}$ - forming austenitic stainless steels (Fe-20Ni-14Cr-2.5Al) has been developed ${ }^{42}$. Alumina-base protective scales present better performance than $\mathrm{Cr}_{2} \mathrm{O}_{3}$, especially in the temperature range of interest (between 600 and $850{ }^{\circ} \mathrm{C}$ ).

For several applications the carburization resistance is more important than oxidation resistance. Carburization is controlled by oxygen and carbon activities. Lowering the oxygen activity tends to make the environment more carburizing ${ }^{36}$.

Austenitic stainless steels are frequently used in the power generation industry at temperatures greater than $650{ }^{\circ} \mathrm{C}$ and stresses of $50 \mathrm{MPa}$ or higher, and are expected to remain in service for more than $100000 \mathrm{~h}^{43}$. Figure 5 presents the creep curves for the AISI 316L(N) steel for long exposure times. This steel represents an evolution, in terms of mechanical properties, of the $316 \mathrm{~L}$ steel, due to minor nitrogen additions. Note that for a relatively low stress condition, such as $120 \mathrm{MPa}$, the plastic deformation at $600{ }^{\circ} \mathrm{C}$ is already significant after 10000 hours. 


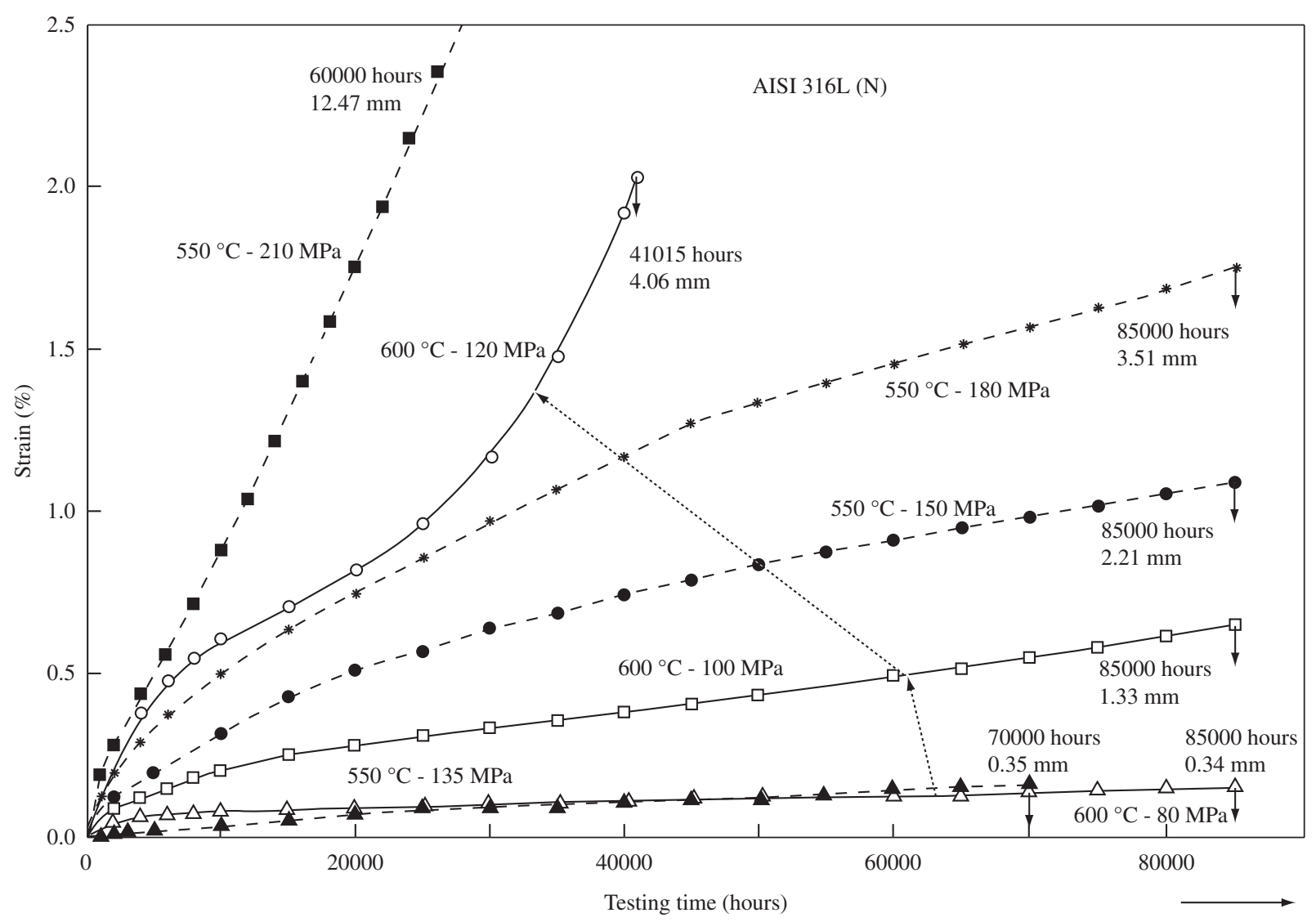

Figure 5. Creep curves for the AISI 316L(N) austenitic stainless steel ${ }^{44,45}$.

The analysis of the data given in the Figures 4 and 5 leads to the conclusion that the maximum usage temperature of the austenitic stainless steels is limited by the creep resistance and not by the oxidation resistance.

Apart from creep, oxidation, hot corrosion and carburization resistance, stainless steels should present microstructural stability. Coarsening of the microstruture and mainly the precipitation of the various phases, such as the intermetallic sigma $(\sigma)$, Laves and chi $(\chi)$ phases, is altogether undesirable, since this leads to a weakened austenite matrix (Figure 6). Historically, sigma $(\sigma)$, Laves and chi $(\chi)$ phases have been perceived as deleterious by the steel and superalloy industries.

The precipitation mechanisms at the different sites are not the same, for instance, whereas the delta ferrite seems to decompose by means of an eutectoid reaction (ferrite $\rightarrow$ sigma + austenite), at the grain boundaries and triple points precipitation occurs by the traditional mechanism (Figures 6 and 7). Precipitation of sigma phase occurs preferentially in the delta ferrite islands (Figure 6a) that is present in the microstructure before creep testing, however sigma phase precipitates also at grain boundaries for longer exposure times also, especially at "triple points" (Figure 6b). Figure 7 summarizes the precipitation sequence of the sigma phase for various precipitation sites such as delta ferrite islands, "triple points" and grain boundaries.

In addition to the loss of ductility, $\sigma$ phase formation may have a negative effect on the corrosion and high-temperature resistance of stainless steels, due to the removal of $\mathrm{Cr}$ and Mo from solid solution ${ }^{47,48}$. Grain boundary attack, caused by $\mathrm{M}_{23} \mathrm{C}_{6}$ precipitation and chromium impoverishment (called in the literature sensitization or intergranular corrosion), is also very frequent in austenitic stainless steels exposed at high temperature ${ }^{49}$.

\section{Performance}

In the previous item we observed that the creep resistance limits the maximum usage temperature of stainless steels (and iron, nickel and cobalt-based superalloys), as opposed to refractory metals, for which maximum usage temperatures are determined by their poor oxidation resistance.

Figure 8 compares creep resistance of various stainless steels and superalloys, where the superiority of the austenitic alloys can be observed, especially of the nickel-base superalloys, precipitation hardened by the $\gamma^{\prime}-\mathrm{Ni}_{3}(\mathrm{Al}, \mathrm{Ti})$.

Table 3 presents the maximum usage temperature, defined by its creep resistance, for different groups of alloys used at high temperatures. The maximum usage temperatures have been assessed for a minimum creep rupture stress of $100 \mathrm{MPa}$ for 1000 hours tests. Despite the testing time $(1000 \mathrm{~h})$ is very short in terms of its application, Table 3 gives a general comparative vision of the different levels of development and improvement made for high temperature materials. The improvement attained in the nickel-base super alloys is clearly visible in this table. It may be also observed that the ironbased austenitic alloys, i.e. the austenitic stainless steels and the Incoloys, have a comparatively lower performance than the nickel or cobalt-base superalloys. Notwithstanding, austenitic stainless steels are widely used because they are easier to process and less expensive, by a factor of 6 to 60 , depending on the alloy, than the nickel or cobalt-base superalloys. 


\section{Final Remarks}

The discovery of stainless steels, about 100 years ago, made possible large scale building of equipments and devices that are corrosion and oxidation resistant. Knowledge acquired in the development and improvements made in these steels has later been used in the development of nickel or cobalt-base superalloys. Despite these developments, austenitic stainless steels are still nowadays widely used, mainly due to their simple processing and their lower price if compared to the nickel or cobalt-base superalloys. For instance, the ASSs are used at high temperatures in the following industries: aerospace, heat treating equipment, mineral and metallurgical processing,

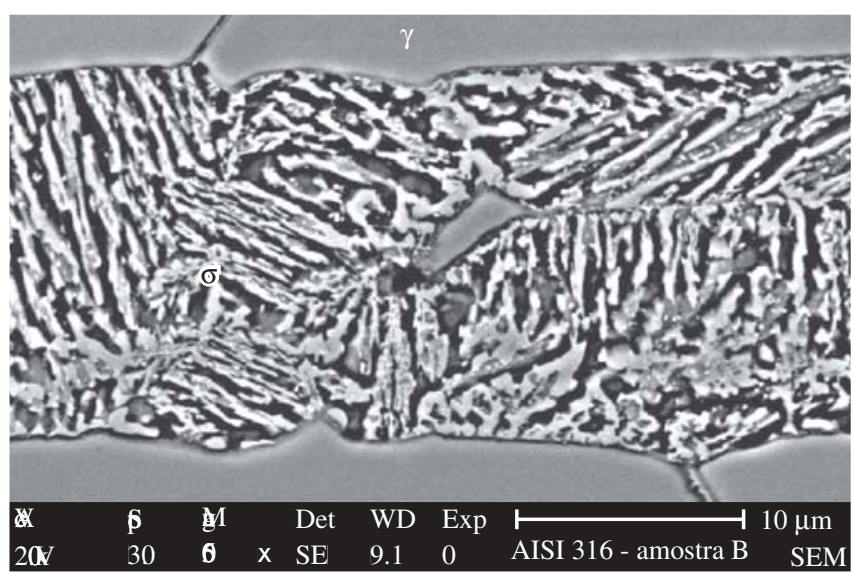

(a)

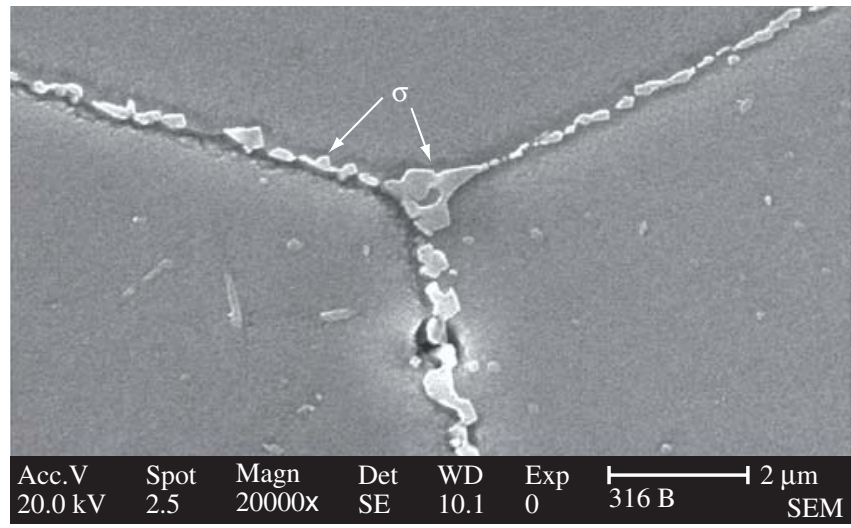

(b)

Figure 6. Micrographs ${ }^{46}$ of the gauge portion of the tested sample $\left(550{ }^{\circ} \mathrm{C}\right.$ $/ 150 \mathrm{MPa} / 85000 \mathrm{~h})$, showing precipitation of sigma phase in AISI $316 \mathrm{~L}(\mathrm{~N})$, a) from delta ferrite islands; and b) at austenite grain boundary and triple points. Etching: V2A-Beize.

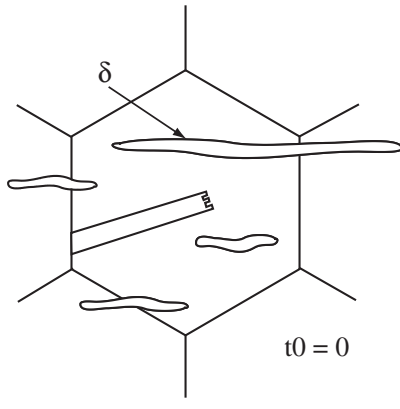

(a)

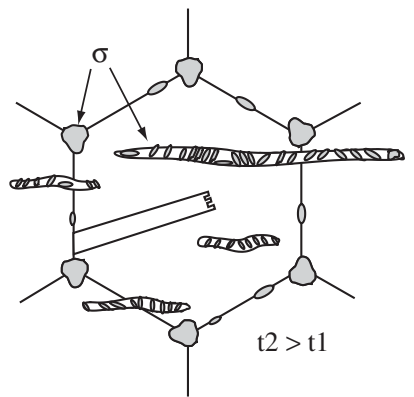

(c)

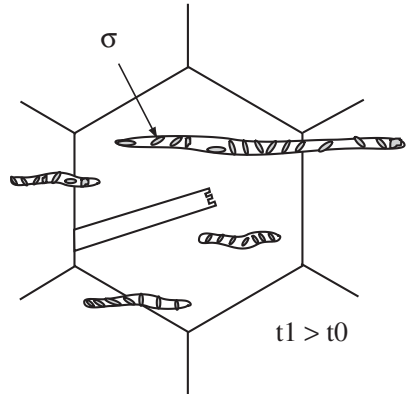

(b)

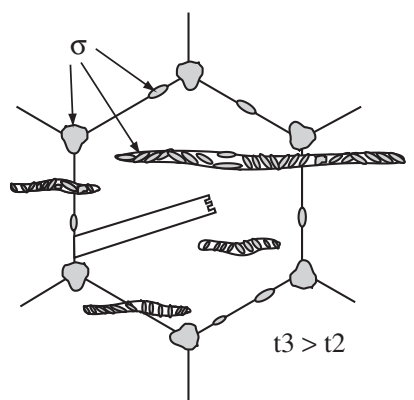

(d)
Figure 7. Schematic representation of sigma phase precipitation in an austenitic stainless steel containing delta ferrite ${ }^{34,35,46}$.

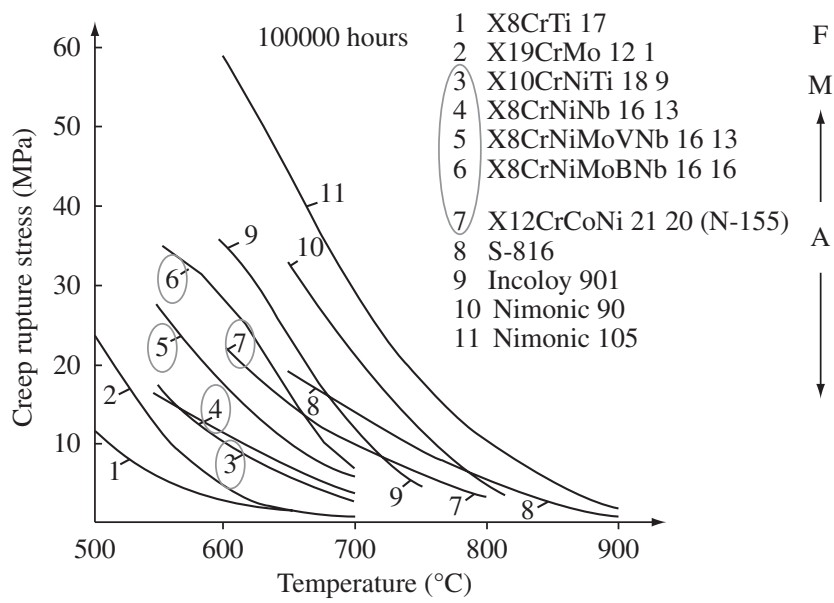

Figure 8. Flow stress curves (rupture strength after 100000 hours) vs. temperature for various stainless steels and superalloys ${ }^{37}$. Where ' $F$ ' means ferritic; 'M' means martensitic and 'A' means austenitic.

Table 3. Main base-metals employed for high temperature applications and associated alloy maximum usage temperatures ${ }^{37}$.

\begin{tabular}{lccc}
\hline \multicolumn{1}{c}{ Base metal } & Melting temperature $\left(\mathrm{T}_{\mathrm{m}}\right)$ in $\left({ }^{\circ} \mathrm{C}\right) ;(\mathrm{K})$ & Max. usage temperature $\left(\mathrm{T}_{\max }\right)\left({ }^{\circ} \mathrm{C}\right) ;(\mathrm{K})$ & $\operatorname{Ratio}_{\left(\mathrm{T}_{\max } / \mathrm{T}_{\mathrm{m}}\right) \text { in }(\mathrm{K} \div \mathrm{K})}$ \\
\hline Nickel & $1455 ; 1728$ & $1050 ; 1323$ & 0.77 \\
Cobalt & $1495 ; 1768$ & $1000 ; 1273$ & 0.72 \\
Iron $(\mathrm{CCC})$ & $1538 ; 1811$ & $650 ; 923$ & 0.51 \\
Iron $(\mathrm{CFC})$ & $1538 ; 1811$ & $750 ; 1023$ & 0.56 \\
Titanium & $1668 ; 1941$ & $550 ; 823$ & 0.42 \\
Zirconium & $1855 ; 2128$ & $450 ; 723$ & 0.34 \\
Niobium & $2477 ; 2750$ & $1200 ; 1473$ & 0.54 \\
Molybdenum & $2623 ; 2896$ & $1300 ; 1573$ & 0.54 \\
Tungsten & $3422 ; 3695$ & $1500 ; 1773$ & 0.48 \\
\hline
\end{tabular}


chemical processing, petroleum refining and petrochemical processing, ceramic, electronic, and glass manufacturing, automotive, pulp and paper, waste incineration, fossil fuel power generation, coal gasification and nuclear.

\section{References}

1. Padilha AF, Plaut RL, Rios, PR. In: Totten GE (editor). Stainless steels heat treatment (chapter 12). Steel heat treatment handbook. 2 ed. Boca Raton (FL, USA): CRC Press; 2007. p. 695-739.

2. Padilha AF, Rios PR. Decomposition of austenite in austenitic stainless steels. ISIJ International (Japan). 2002; 42(4):325-337.

3. Allan GK. Solidification of austenitic stainless steels. Ironmaking and Steelmaking. 1995; 22(6):465-477.

4. Padilha AF, Guedes LC. Aços inoxidáveis austeníticos: microestrutura e propriedades. Hemus Editora Limitada, São Paulo, 1994, p. 27-61. (in portuguese).

5. Ahlblom B, Sandström, R. Hot workability of stainless steels: influence of deformation parameters, microstructural components, and restoration processes. International Metals Reviews. 1982; 27(1):1-27.

6. Myllykoski L, Suutala N. Effect of solidification mode on hot ductility of austenitic stainless steels. Metals Technology. 1983; 10(12):453-460.

7. Kim SK, Shin YK, Kim. NJ, Distribution of $\delta$ ferrite content in continuously cast type 304 stainless steel slabs. Ironmaking and Steelmaking. 1995; 22(4):316-325.

8. Czerwinski F, Cho JY, Brodtka A, Zielinska-Lipiec A, Sunwoo JH, Szpunar JA. The edge-cracking of AISI 304 stainless steel during hot-rolling. Journal of Materials Science. 1999; 34(19):4727-4735.

9. Mintz B, Cowley A, Abushosha R. Importance of columnar grains in dictating hot ductility of steels. Metals Science and Technology. 2000; 16(1):1-5.

10. Kim SH, Moon HK, Kang T, Lee CS. Dissolution kinetics of delta ferrite in AISI 304 stainless steel produced by strip casting process. Materials Science and Engineering A. 2003; A356(1-2):390-398.

11. Keown SR. In: Sellars CM and Davies GJ (editors). Hot ductility of wrought austenitic stainless steels. Part I: Effect of alloying additions. In: Hot working and forming processes. The Metals Society. London; 1980. p. 140-147.

12. Martins LFM, Plaut RL, Padilha AF. Effect of carbon on the cold-worked state and annealing behaviour of two $18 \mathrm{wt} \% \mathrm{Cr}-8 \mathrm{wt} \% \mathrm{Ni}$ austenitic stainless steels. ISIJ International (Japan). 1998; 38(6):572-579.

13. Padilha AF, Plaut RL, Rios PR. Annealing of cold-worked austenitic stainless steels. ISIJ International (Japan). 2003; 43(2):135-143.

14. Haeßner F, Plaut RL, Padilha AF. Separation of static recrystallization and reverse transformation of deformation-induced martensite in an austenitic stainless steel by calorimetric measurements. ISIJ International (Japan). 2003; 43(9):1472-1474.

15. Behrens BA, Doenge E, Springub B. Transformation induced martensite evolution in metal forming processes of stainless steels. Steel Research. 2004; 75(7):475-482.

16. Santacreu PO, Glez JC, Chinouilh G, Frölich T. Behaviour model of austenitic stainless steels for automotive structural parts. Steel Research International. 2006; 77(9-10):686-691.

17. Smaga M, Walther F, Eifler D. Investigation and modelling of the plasticity-induced martensite formation in metastable austenites. International Journal of Materials Research (formerly Zeitschrift für Metallkunde). 2006; 97(12):1648-1655.

18. Padilha AF, Dutra JC, Randle V. Interaction between precipitation, normal grain growth, and secondary recrystallisation in austenitic stainless steel containing particles. Materials Science and Technology. 1999; 15(9):1009-1014.

19. Dutra JC, Siciliano Jr F, Padilha AF. Interaction between second-phase particle dissolution and abnormal grain growth in an austenitic stainless steel. Materials Research (Brazil). 2002; 5(3):379-384.
20. Schramm RE, Reed RP. Stacking fault energies of seven commercial austenitic stainless steels. Metallurgical Transactions A. 1975; 6(7):1345-1351.

21. Borges JFA, Padilha AF, Imakuma, K. Determinação da energia de defeito de empilhamento em metais e ligas com estrutura cúbica de face centrada por difração de raios-X. Revista de Física Aplicada e Instrumentação. 1986; 1(4):335-351. (in portuguese).

22. Martinez LG, Imakuma K, Padilha AF. Influence of niobium on stacking fault energy of all-austenite stainless steels. Steel Research. 1992; 63(5):221-223.

23. Reick W, Pohl M, Padilha AF. Determination of stacking fault energy of austenite in a duplex stainless steel. Steel Research. 1996; 67(6):253-256.

24. Weiss B, Stickler R. Phase instabilities during high temperature exposure of 316 austenitic stainless steel. Metallurgical Transactions. 1972; 3(4):851-866.

25. Chastell DJ, Flewitt PEJ. The formation of the $\sigma \pi \eta \alpha$ se during long term high temperature creep of type 316 austenitic stainless steel. Materials Science and Engineering. 1979; 38(2):153-162.

26. Dean MS, Plumbridge WJ. Prediction of sigma phase formation in stainless steels. Nuclear Energy. 1982; 21(2):119-135.

27. Barcik J. The process of $\sigma$-phase solution in 25 pct Cr-20 pct Ni austenitic steels. Metallurgical Transactions A. 1987; 18A(7):1171-1177.

28. Barcik J. Mechanism of $\sigma$ phase precipitation in $\mathrm{Cr}-\mathrm{Ni}$ austenitic steels. Materials Science and Technology. 1988; 4(1):5-15.

29. Kington AV, Noble FW. Formation of $\sigma$ phase in wrought 310 stainless steel. Materials Science and Technology. 1995; 11(3):268-283.

30. Okabayashi H. Mathematical approach to $\sigma$ phase precipitation in austenitic stainless steel welds. Materials Transactions (JIM). 1996; 37(5):970-974.

31. Heino S, Knutson-Wedel EM, Karlsson B. Precipitation behaviour in heat affected zone of welded superaustenitic stainless steel. Materials Science and Technology. 1999; 15(1):101-108.

32. Sourmail T. Precipitation in creep resistant austenitic stainless steels. Materials Science and Technology. 2001; 17(1):1-14.

33. Wasnik DN, Dey GK, Kain V, Samajdar I. Precipitation stages in a 316L austenitic stainless steel. Scripta Materialia. 2003; 49(2):135-141.

34. Escriba Villanueva DM, Pimenta Jr FC, Plaut RL, Padilha AF. Comparative study on sigma phase precipitation of three types of stainless steels: austenitic, superferritic and duplex. Materials Science and Technology. 2006; 22(9):1098-1104.

35. Padilha AF, Escriba DM, Materna-Morris E, Rieth M, Klimenkov M. Precipitation in AISI $316 \mathrm{~L}(\mathrm{~N})$ during creep tests at 550 and $600{ }^{\circ} \mathrm{C}$ up to 10 years. Journal of Nuclear Materials. 2007; 362(1):132-138.

36. Davis JR, editor. ASM specialty handbook: stainless steels. ASM International, Ohio (USA); 1994. p. 205-228.

37. Dienst W. Hoch-Temperatur-Werkstoffe. Werkstoffetechnische Verlagsgesellshaft m.b.H., Karlsruhe (Germany); 1978.

38. Morris LA. In: Peckner D, Bernstein IM (editors). Resistance to corrosion in gaseous atmospheres (Chapter 17). Handbook of stainless steels. New York: Mcgraw-Hill Book Company; 1977. p. 17-1 - 17-33.

39. Dillon CP. High-temperature applications (Chapter 12). In: Corrosion resistance of stainless steels. New York: Marcel Dekker; 1995. p. 245-269.

40. Pillis MF, Araújo EG, Ramanathan LV. Effect of rare earth oxide additions on oxidation behavior of AISI 304L stainless steel. Materials Research (Brazil). 2006; 9(4):375-379.

41. Paúl A, Sánchez R, Montes OM, Odriozola JA. The role of silicon in the reactive-elements effect on the oxidation of conventional austenitic stainless steel. Oxidation of Metals. 2007; 67(1-2):87-105.

42. Yamamoto Y, Brady MP, Lu ZP, Maziasz PJ, Liu CT, Pint BA, More $\mathrm{KL}$, Meyer HM, Payzant EA. Creep-resistant, $\mathrm{Al}_{2} \mathrm{O}_{3}$-forming austenitic stainless steels. Science. 2007; 316(5823):433-436. 
43. Sourmail T, Bhadeshia HKDH, MacKay DJC. Neural network model of creep strength of austenitic stainless steels. Materials Science and Technology. 2002; 18(6):655-663.

44. Schirra M, Falkenstein A, Heger S. Experimentelle Ergebnisse zum Kriechverhalten des Strukturwerkstoffes 316-L(N) - DIN 1.4909 in niedrigen Spannungsbereich bei $550^{\circ}$ und $600{ }^{\circ} \mathrm{C}$ (Abschlussbericht). Report FZKA 6699, Forschungszentrum Karlsruhe, Germany, February 2002. (in German).

45. Rieth M, Falkenstein A, Graf P, Reger S, Jäntsch U, Klimiankou M, Materna-Morris E, Zimmermann H. Creep of the austenitic steel AISI 316 L(N): experiment and models. Report FZKA-7065, Forschungszentrum Karlsruhe, Germany, November 2004.
46. Escriba Villanueva DM. Precipitação de fase sigma em três tipos de aços inoxidáveis: austenítico, superferrítico e dúplex. [tese de doutorado]. São Paulo, Brazil: Escola Politécnica da USP; 2005. (in Portuguese).

47. Strutt AJ, Vecchio KS. Simultaneous oxidation and sigma-phase formation in a stainless steel. Metallurgical and Materials Transactions A. 1999; 30A(2):355-362.

48. Terada M, Escriba DM, Costa I, Materna-Morris E, Padilha AF. Investigation on the intergranular corrosion resistance of the AISI $316 \mathrm{~L}(\mathrm{~N})$ stainless steel after long time creep test at $600{ }^{\circ} \mathrm{C}$. Materials Characterization. "in press"; 2007.

49. Terada M, Saiki M, Costa I, Padilha AF. Microstructure and intergranular corrosion of the austenitic stainless steel 1.4970. Journal of Nuclear Materials. 2006; 358(1):40-46. 